\title{
Aplikasi minyak sulfat dari minyak kelapa sawit (Elaeis guinensis JACQ) sebagai fatliquoring
}

\section{The application of sulphated oil from palm oil (Elaeis guinensis JACQ) as leather fatliquoring}

\author{
Emiliana Kasmudjiastuti*, Rihastiwi Setiya Murti, Tiyastiti Suraya, Sugihartono \\ Balai Besar Kulit, Karet dan Plastik, Jl. Sokonandi No. 9, Yogyakarta 55166, Indonesia \\ *Penulis korespondensi. Telp.: +62 274 512929, 563939, Fax.: +62 274563655 \\ E-mail: emilianakasmudjiastuti@gmail.com
}

Diterima: 4 Oktober 2019 Direvisi: 9 Desember $2019 \quad$ Disetujui: 9 Desember 2019

\begin{abstract}
The research was conducted with the aim to study the effect of $\mathrm{H}_{2} \mathrm{SO}_{4}$ and sulphatations time to the quality of the tanned leather. Other materials used was palm oil (with no brand), $\mathrm{H}_{2} \mathrm{SO}_{4}, \mathrm{NaCl}$ and $\mathrm{NaOH}$. The variables observed were the amount of $\mathrm{H}_{2} \mathrm{SO}_{4}$ and sulphatations time of the sulphated oils. Several series of test was conducted to the sulphated oils and fatliquored hides using the oils. The test includes water content, $\mathrm{pH}$, oil content, alkalinity number, saphonification number, ash content, iodine number, and bounded $\mathrm{SO}_{3}$ content for the sulphated oils. Fatliquored hides test including organoleptic test, physical and chemical test (including thickness, tear strength, tensile strength, elongations, and oil content) and SEM-EDX test. All of the sulphated oils could be applied to the hides with $8 \%$ ratio with no visible fatty spew on the hides surface. The optimum ratio for the sulphated oils was synthesize using $12.5 \% \mathrm{H}_{2} \mathrm{SO}_{4}$ and 4 hour sulphatation time. The sulphated oils on those variation (12.5-4) was complied with the Indian Standard IS:6357-1971, with specific compositions of 5.16\% water content, $2.17 \%$ ash content, $0.79 \%$ total alkalinity, $88.42 \%$ fat content, 6.60 of $\mathrm{pH}$, bounded $\mathrm{SO}_{3} 6.49 \%$. The quality of tanned leather was depended on $\mathrm{H}_{2} \mathrm{SO}_{4}$ amount (10 and $12.5 \%$ ) and sulphatations time $(1,2,3$, and 4 hour). An 8\% application of the sulphated oils (12.5-4) on hides was the best composition, as the tanned leather complied with the SNI requirement of SNI 0253:2009 Kulit bagian atas alas kaki-kulit kambing (top hides

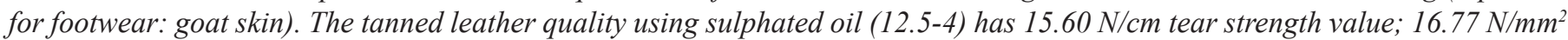
tensile strength; $48.36 \%$ elongation, and 7.57 oil content with no visible fatty spew on the surface.
\end{abstract}

Keywords: palm oil, sulfate oil, tanned leather quality.

\begin{abstract}
ABSTRAK
Tujuan penelitian ini adalah untuk mengetahui pengaruh jumlah $\mathrm{H}_{2} \mathrm{SO}_{4}$ dan waktu sulfatasi terhadap kualitas kulit tersamak. Bahan baku yang digunakan dalam penelitian ini adalah minyak kelapa sawit curah (tidak bermerek) dan bahan lain seperti $\mathrm{H}_{2} \mathrm{SO}_{4}, \mathrm{NaCl}$, dan $\mathrm{NaOH}$. Variabel yang diamati meliputi variasi jumlah $\mathrm{H}_{2} \mathrm{SO}_{4}$ dan waktu sulfatasi pada pembuatan minyak sulfat. Pengujian dilakukan terhadap minyak sulfat yang dihasilkan dan kulit jadi hasil aplikasi minyak sulfat pada kulit. Pengujian minyak sulfat meliputi uji kimia: kadar air, pH, kadar minyak, total alkalinitas, angka penyabunan, kadar abu, angka Iodine dan kadar $\mathrm{SO}_{3}$ terikat. Pengujian kulit meliputi pengamatan kulit hasil aplikasi minyak secara visual, uji fisis dan kimia (meliputi ketebalan, kekuatan sobek, kekuatan tarik, kemuluran, dan kadar minyak) dan uji SEM-EDX. Semua minyak sulfat hasil penelitian dapat diaplikasikan pada kulit dengan jumlah minyak 8\% dan tidak timbul bercak-bercak lemak (fatty spew) pada permukaan kulit. Minyak sulfat yang optimal adalah minyak sulfat dengan jumlah $\mathrm{H}_{2} \mathrm{SO}_{4}$ sebesar $12,5 \%$ dan waktu sulfatasi 4 jam. Secara kimia minyak sulfat (12,5 - 4) memenuhi persyaratan IS: 6357-1971, spesifikasi minyak sulfat untuk kulit dengan nilai kadar air 5,16\%; kadar abu 2,17\%; total alkalinitas 0,79\%; kadar lemak 88,42\%; pH 6,60; kadar $\mathrm{SO}_{3}$ terikat 6,49\%. Jumlah $\mathrm{H}_{2} \mathrm{SO}_{4}(10$ dan $12,5 \%$ ) dan waktu sulfatasi $(0,1,2,3$, dan 4 jam) berpengaruh terhadap kualitas kulit tersamak. Aplikasi 8\% minyak sulfat (12,5 - 4) pada kulit merupakan perlakuan yang optimal dan memenuhi persyaratan SNI 0253:2009 Kulit bagian atas alas kaki - kulit kambing (BSN, 2009). Kualitas kulit tersamak yang dihasilkan yaitu dengan nilai kekuatan sobek 15,60 N/cm ; kekuatan tarik 16,77 N/mm²; kemuluran 48,36\% dan kadar minyak 7,57\% dan secara visual kulit hasil aplikasi minyak sulfat (12,5 - 4) tidak nampak adanya fatty spew.
\end{abstract}

Kata kunci: minyak kelapa sawit, minyak sulfat, kualitas kulit tersamak.

\section{PENDAHULUAN}

Tanaman kelapa sawit (Elaeis guinensis JACQ) termasuk dalam famili palmae. Salah satu dari beberapa tanaman golongan palm yang dapat menghasilkan minyak adalah kelapa sawit (Elaeis guinensis JACQ) (Rofiqi, 2016). Minyak kelapa sawit terdiri atas trigliserida yang 
merupakan ester dari gliserol dengan tiga molekul asam lemak (Kassahun, 2014) dan mempunyai komposisi asam lemak jenuh dan tidak jenuh dengan proporsi yang seimbang. Komposisi asam lemak minyak sawit terdiri dari $40 \%$ asam oleat (tidak jenuh tunggal), $10 \%$ asam linoleat (tidak jenuh ganda), $44 \%$ asam palmitat (jenuh) dan 4,5\% asam stearat jenuh (Hariyadi, 2010).

Proses peminyakan adalah perlakuan memasukkan minyak yaitu emulsi minyak dalam air yang dilarutkan dengan air hangat ke dalam matriks jaringan kulit (Nyamunda et al., 2013; Tawfik, 2017). Umumnya proses yang dilakukan pada tahap akhir sebelum proses pengeringan dan finishing yang dapat memberikan kelemasan dan fleksibilitas pada kulit (Tawfik, 2017). Fungsi minyak ada tiga, yaitu mencegah jaringan kulit resticking selama pengeringan; untuk melemaskan kulit dan meningkatkan kekuatan (improving strength). Dalam industri kulit umumnya menggunakan minyak sulfat atau sulfit (Tournier, 2017).

Fatliquoring agent yang digunakan dalam proses peminyakan dicampur dengan bahan pengemulsi (emulsifier) atau surfaktan ke dalam komposisi fatliquoring agent (Wang et al., 2012; Nyamunda et al., 2013; Tawfik et al., 2017). Minyak sulfat mempunyai partikel yang kecil dan mempunyai kapasitas mengikat yang tinggi pada jaringan kulit karena elaborasi secara kimia dengan emulsifier. Minyak sulfat adalah minyak anionic, dapat mengikat gugus-gugus amino dari kolagen (Santos \& Gutterres, 2007), dispersinya bagus dan stabil pada $\mathrm{pH}$ rendah, sehingga banyak digunakan di industri kulit (Kassahun, 2014). Minyak terdiri dari emulsifier dan fatty matter.

Minyak yang digunakan pada proses peminyakan kulit umumnya menggunakan minyak yang sudah di sulfatasi yang berasal dari minyak ikan, hewan dan nabati serta minyak sintetis. Secara kimia minyak ikan, hewan dan nabati mengandung trigliserida (Strijbos et al., 2012). Untuk dapat digunakan sebagai fatliquor maka minyak tersebut harus dilakukan proses sulfatasi dan minyak yang dihasilkan disebut dengan minyak sulfat. Minyak sulfat diperoleh dengan mereaksikan minyak nabati atau minyak hewani dengan menggunakan asam sulfat atau gas $\mathrm{SO}_{3}$ pada suhu rendah. Melalui reaksi ini kelompok senyawa polar yang bersifat hidrofilik dimasukkan ke dalam struktur bahan minyak, sehingga terbentuk emulsi minyak dalam air (Sarkar, 1995). Kassahun (2014) menambahkan bahwa minyak sulfat yang dibuat dengan menambahkan asam sulfat ke dalam minyak perlu pengawasan suhu dan waktu pengadukan, diikuti dengan pencucian asam dengan larutan garam untuk menghilangkan kelebihan asam dan dinetralisasi menggunakan sodium hidroksida sampai $\mathrm{pH}$ yang diinginkan.

Beberapa penelitian aplikasi minyak kelapa sawit untuk peminyakan kulit telah dilakukan diantaranya penggunaan $6 \%$ minyak fosfat dari minyak kelapa sawit bekas penggorengan potato chip untuk peminyakan kulit samak krom, uji yang dilakukan kekuatan tarik, kemuluran dan kekuatan jahit (Megahed \& Nashy, 2010); penerapan minyak sulfat $(0 ; 5 ; 10 ; 15 \%)$ dari minyak bimoli pada kulit wetblue sapi untuk garmen ditinjau dari kekuatan tarik dan elongasinya (Nurbalia, 2000). Secara umum hasil penelitian-penelitian tersebut diatas, belum dilakukan uji spesifikasi minyak sulfat yang dipersyaratkan untuk peminyakan kulit (IS: 6357-1971: Specification for Sulphated Oil for Leather Fatliquoring: Kadar air, pH, kadar minyak, total alkalinitas, kadar abu, kadar $\mathrm{SO}_{3}$ terikat). Sedangkan untuk hasil penerapan minyak sulfat pada kulit yang dilakukan oleh Nurbalia (2000) terdapat fattyspew (bercak-bercak lemak) pada kulitjadinya dengan aplikasi minyak sulfat lebih dari 5\%. Kasmudjiastuti et al. (2018) melaporkan bahwa penggunaan $6 \%$ minyak sulfat dari sulfatasi minyak kelapa sawit curah (tanpa merk) menggunakan $25 \% \mathrm{H}_{2} \mathrm{SO}_{4}$ dengan waktu sulfatasi 3 jam dapat diaplikasikan pada kulit. Namun penggunaan jumlah $\mathrm{H}_{2} \mathrm{SO}_{4}$ yang besar akan mempengaruhi kulit jadi yang dihasilkan, yaitu kulit terasa berat. Menurut Covington (2009) sulfatasi minyak bisa dilakukan menggunakan $10-20 \%$ asam sulfat. Oleh karena itu pada penelitian ini dicoba mengurangi jumlah penggunaan $\mathrm{H}_{2} \mathrm{SO}_{4}$ pada proses sulfatasi yaitu menggunakan 10 dan $12,5 \%$ asam sulfat, dengan variasi waktu sulfatasi $0,1,2,3$, dan 4 jam dan jumlah minyak sulfat yang diaplikasikan pada kulit domba $8 \%$ diharapkan tidak timbul bercak-bercak lemak pada kulit kras. Tujuan penelitian ini adalah untuk mengetahui pengaruh jumlah $\mathrm{H}_{2} \mathrm{SO}_{4}$ dan waktu sulfatasi terhadap kualitas kulit yang dihasilkan.

\section{BAHAN DAN METODE \\ Bahan}

Bahan yang digunakan dalam penelitian ini adalah minyak kelapa sawit tanpa kemasan (minyak curah) dari distributor minyak curah dari Yogyakarta yang belum disulfatasi, minyak sulfat komersial (G-GS), $\mathrm{H}_{2} \mathrm{SO}_{4}$ teknis $98 \%, \mathrm{NaCl} 10 \%$ teknis, $\mathrm{NaOH}$, es batu, ice gel, kulit domba wet blue, wetting agent, asam formiat, dyestuffs, bahan penyamak ulang: syntan dan mimosa, anti jamur.

\section{Alat}

Alat yang digunakan dalam penelitian ini meliputi timbangan, pipet tetes, piranti gelas seperti gelas beker, termometer, pengaduk kaca, gelas ukur, dan corong pemisah, over head stirrer merek IKA Germany, klem dan statif, baskom stainless steel, LED Digital Hotplate Magnetic stirrer serial No. MR 174A10002660, drum eksperimen Otto Specht serial number 80304, alat uji kekuatan tarik (Zwick Roell ZO20 tipe KAP-TC), dan scanning electron microscope (SEM) JSM-6510LA.

\section{Metode \\ Sintesis minyak sulfat}

Seratus gram minyak kelapa sawit curah dalam gelas beker yang dimasukkan kedalam mangkok stainless steel yang berisi es, diaduk dengan mixer dengan kecepatan tetap $300 \mathrm{rpm}$, ditambahkan sulfating agent (10 dan $12,5 \% \mathrm{H}_{2} \mathrm{SO}_{4}$, dari berat minyak untuk variasi perlakuan) perlahan-lahan suhu dijaga tidak lebih dari $20^{\circ} \mathrm{C}$. Proses 
sulfatasi dengan variasi waktu $0,1,2,3$, dan 4 jam. Minyak sulfat dicuci dengan larutan garam jenuh $(10 \% \mathrm{NaCl})$ suhu $35^{\circ} \mathrm{C}$ sebanyak tiga kali. Kemudian minyak dipisahkan dengan air garam. Minyak sulfat dinetralkan dengan larutan 50\% NaOH sampai pH 6,5-7 (Kasmudjiastuti et al, 2018).

\section{Aplikasi minyak sulfat pada kulit}

Aplikasi minyak sulfat pada kulit dibuat untuk artikel leather goods (barang-barang kulit), proses penyamakan kulit dimulai dari kulit wet blue dari kulit domba. Kulit wet blue dicuci dengan air selama 10 menit dan air di buang. Kemudian kulit dinetralisasi menggunakan $1 \%$ sodium formate, $2 \%$ Tanigan PAK dalam 150\% air, drum diputar selama 20 menit. Kemudian ditambah $0,8 \%$ soda kue, drum diputar selama 45 menit, kulit diuji menggunakan bromo cresol green ( $\mathrm{pH} 5-5,5)$. Selanjutnya kulit dicuci dan disamak ulang menggunakan $2 \%$ Novaltan PF, $4 \%$ Tanicor RS 38, 3\% Mimosa, dan 3\% Tanicor TNB, drum diputar selama 45 menit. Lalu ditambah $2 \%$ cat dasar dan minyak hasil penelitian $8 \%$ dari variasi jumlah $\mathrm{H}_{2} \mathrm{SO}_{4}(10$ dan $12,5 \%)$ dan waktu sulfatasi $(0,1,2,3$, dan 4 jam) selama 60 menit, kemudian difiksasi menggunakan $1 \%$ asam formiat.

\section{Pengujian}

Pengujian meliputi uji kimia minyak sulfat (kadar air, kadar abu, total alkalinitas, kadar minyak/lemak, $\mathrm{pH}$, angka penyabunan, angka Iodine dan kadar $\mathrm{SO}_{3}$ terikat), pengamatan kulit tersamak secara visual, uji fisis dan kimiawi kulit tersamak dan uji SEM-EDX.

\section{HASIL DAN PEMBAHASAN}

\section{Sifat-Sifat Kimia Minyak Sulfat}

Hasil analisis kimia minyak sulfat meliputi, kadar air, kadar abu, angka penyabunan, total alkalinitas, kadar minyak/lemak, $\mathrm{pH}$, kadar $\mathrm{SO}_{3}$ terikat, dan angka Iodine dapat dilihat pada Tabel 1.

\section{Kadar Air}

Pengujian kadar air dilakukan untuk mengukur besarnya kandungan air yang terdapat dalam minyak. Kadar air minyak sulfat hasil penelitian berkisar antara 1,43-5,16\%, yang ditunjukkan pada Tabel 1. Kadar air minyak sulfat hasil penelitian termasuk minyak sulfat komersial, semuanya memenuhi persyaratan IS:63571971, spesifikasi minyak sulfat untuk kulit yang mempersyaratkan kadar air maksimum 35\%. Hasil uji kadar air menunjukkan bahwa ada kecenderungan semakin lama waktu sulfatasi baik pada kadar $10 \%$ dan 12,5\% $\mathrm{H}_{2} \mathrm{SO}_{4}$, maka kadar air yang dihasilkan semakin besar. Semakin banyak asam sulfat yang ditambahkan, maka kadar air yang dihasilkan juga semakin banyak. Hal ini ditunjukkan pada reaksi sulfatasi seperti pada Gambar1.

\section{Kadar Abu}

Kadar abu dalam minyak sulfat menunjukkan kandungan mineral yang ada di dalam minyak tersebut. Kadar abu yang dihasilkan dari minyak hasil penelitian berkisar antara 0,71 - 2,17\%, yang ditunjukkan dalam Tabel 1. Kadar abu minyak sulfat hasil penelitian termasuk minyak sulfat komersial, semuanya memenuhi persyaratan IS: 6357-1971, spesifikasi minyak sulfat untuk kulit yang mempersyaratkan kadar abu maksimum 3\%.

Hasil uji kadar abu pada penggunaan $10 \% \mathrm{H}_{2} \mathrm{SO}_{4}$ nilainya lebih rendah daripada penggunaan $12,5 \% \mathrm{H}_{2} \mathrm{SO}_{4}$, hal ini menunjukkan bahwa semakin besar jumlah $\mathrm{H}_{2} \mathrm{SO}_{4}$ yang ditambahkan maka nilai kadar abu yang dihasilkan semakin besar. Hasil uji kadar abu pada penggunaan $12,5 \% \mathrm{H}_{2} \mathrm{SO}_{4}$ menunjukkan bahwa semakin lama waktu sulfatasi, maka kadar abu yang dihasilkan semakin besar. Hal ini mengindikasikan bahwa semakin lama waktu sulfatasi maka semakin banyak asam sulfat yang bereaksi dengan asam lemak dari minyak, sehingga pada analisis kadar abu dalam minyak sulfat akan dihasilkan nilai kadar abu yang lebih tinggi.

\section{Angka Penyabunan}

Angka penyabunan adalah jumlah miligram $\mathrm{KOH}$ yang diperlukan untuk menyabunkan satu gram minyak/ lemak. Analisa angka penyabunan dimaksudkan untuk mengetahui jumlah gugus sulfat yang terikat pada minyak. $\mathrm{KOH}$ yang ditambahkan pada minyak sulfat akan memutuskan ikatan yang terjadi antara asam sulfat dan minyak, selanjutnya $\mathrm{KOH}$ bereaksi dengan asam lemak dari minyak menggantikan posisi asam sulfat. Pada reaksi penyabunan terjadi reaksi gugus $\mathrm{SO}_{4} \mathrm{H}$ dari minyak sulfat dan reaksi terhadap gugus $\mathrm{COOH}$ dari asam lemak.

Angka penyabunan minyak sulfat hasil penelitian berkisar antara 26,86-121,70 yang ditunjukkan pada Tabel 1. Angka penyabunan menunjukkan bahwa ada kecenderungan semakin lama waktu sulfatasi baik pada kadar $10 \%$ maupun $12,5 \% \mathrm{H}_{2} \mathrm{SO}_{4}$, maka angka penyabunan yang dihasilkan semakin besar. Semakin besar jumlah asam sulfat dan lama pengadukan (waktu sulfatasi), memungkinkan molekul-molekul asam sulfat bereaksi dengan ikatan rangkap dari asam lemak penyusun minyak, sehingga ikatan rangkap teradisi oleh asam sulfat

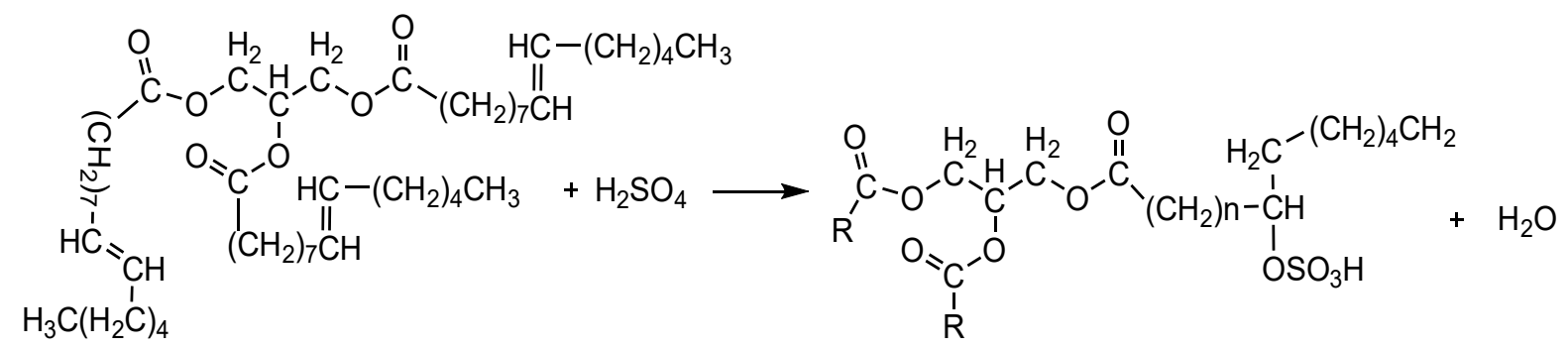

Gambar 1. Reaksi sulfatasi minyak kelapa sawit dengan $\mathrm{H}_{2} \mathrm{SO}_{4}$. 
Tabel 1. Hasil uji sifat kimia minyak sulfat.

\begin{tabular}{|c|c|c|c|c|c|c|c|c|c|c|c|c|c|}
\hline \multirow[t]{2}{*}{ No } & \multirow{2}{*}{$\begin{array}{c}\text { Parameter } \\
\text { uji }\end{array}$} & \multicolumn{12}{|c|}{ Kode perlakuan } \\
\hline & & $10-0$ & $10-1$ & $10-2$ & $10-3$ & $10-4$ & $12,5-0$ & $12,5-1$ & $12,5-2$ & $12,5-3$ & $12,5-4$ & G-GS & IS \\
\hline 1. & $\begin{array}{l}\text { Kadar air, } \\
\%\end{array}$ & 1,43 & 1,78 & 1,48 & 1,72 & 1,62 & 2,21 & 4,79 & 4,73 & 4,53 & 5,16 & 25,09 & Max.35 \\
\hline 2. & $\begin{array}{l}\text { Kadar abu, } \\
\%\end{array}$ & 0,71 & 1,10 & 1,16 & 0,97 & 0,72 & 0,76 & 1,67 & 1,82 & 1,89 & 2,17 & 2,83 & Max.3 \\
\hline 3. & $\begin{array}{l}\text { Angka } \\
\text { penyabu } \\
\text { nan }\end{array}$ & 36,5 & 34,7 & 63,8 & 43,30 & 66,5 & 26,86 & 86,05 & 86,27 & 60,97 & 121,7 & 86,09 & - \\
\hline 4. & $\begin{array}{l}\text { Total } \\
\text { alkalinitas, } \\
\text { ml.eq/10 g }\end{array}$ & 1,62 & 1,60 & 1,15 & 1,18 & 1,15 & 0,71 & 1,04 & 0,98 & 0,66 & 0,79 & 1,51 & Max.3 \\
\hline 5. & $\begin{array}{l}\text { Kadar } \\
\text { minyak, \% }\end{array}$ & 94,31 & 93,68 & 91,38 & 94,53 & 92,62 & 84,50 & 86,39 & 88,42 & 86,39 & 88,42 & 64,39 & Min.60 \\
\hline 6. & $\mathrm{pH}$ & 7,50 & 7,75 & 7,40 & 7,20 & 7,30 & 7,40 & 7,00 & 6,90 & 6,80 & 6,60 & 5,46 & $6,5-8$ \\
\hline 7. & $\begin{array}{l}\text { Kadar } \mathrm{SO}_{3} \\
\text { terikat }\end{array}$ & 5,49 & 4,44 & 4,56 & 4,63 & 5,69 & 7,71 & 7,81 & 6,63 & 7,45 & 6,49 & 5,09 & - \\
\hline 8. & $\begin{array}{l}\text { Angka } \\
\text { Iodine }\end{array}$ & 29,2 & 34,2 & 34,8 & 32,65 & 37,8 & 43,0 & 38,94 & 42,15 & 42,15 & 38,84 & - & - \\
\hline
\end{tabular}

yang menyebabkan jumlah angka penyabunan semakin tinggi (Helmi, 2001). Hal ini dapat dilihat bahwa angka penyabunan tertinggi pada penggunaan $12,5 \% \quad \mathrm{H}_{2} \mathrm{SO}_{4}$ dengan waktu sulfatasi 4 jam yaitu sebesar $121,7 \%$. Bila dibandingkan dengan asam sulfat komersial, angka penyabunan nilainya lebih tinggi, yang menunjukan bahwa banyak gugus sulfat yang terikat pada minyak.

\section{Total Alkalinitas}

Nilai total alkalinitas minyak sulfat hasil penelitian berkisar antara 0,66-1,62, yang ditunjukkan pada Tabel 1 . Total alkalinitas minyak sulfat hasil penelitian termasuk minyak sulfat komersial, semuanya memenuhi persyaratan Indian Standard IS:6357-1971 Specification for sulphated oil for leather fatliquoring, spesifikasi minyak sulfat untuk kulit, mempersyaratkan total alkalinitas maksimum $3 \%$. Jumlah $\mathrm{H}_{2} \mathrm{SO}_{4}$ dan waktu sulfatasi berpengaruh terhadap total alkalinitas yang terdapat pada minyak sulfat yang dihasilkan. Semakin banyak jumlah $\mathrm{H}_{2} \mathrm{SO}_{4}$ yang ditambahkan, maka nilai total alkalinitas semakin rendah. Semakin lama waktu sulfatasi, maka nilai total alkalinitas ada kecenderungan menurun. Hal ini menunjukkan bahwa jumlah $\mathrm{H}_{2} \mathrm{SO}_{4}$ yang optimal pada penelitian ini pada penggunaan $12,5 \% \mathrm{H}_{2} \mathrm{SO}_{4}$, apabila dibandingkan dengan nilai total alkalinitas minyak sulfat komersial, hasilnya lebih baik karena lebih rendah nilainya.

\section{Kadar Minyak}

Kadar minyak dalam minyak sulfat hasil penelitian berkisar antara 84,5-94,53\% yang ditunjukkan pada Tabel 1. Kadar minyak dari minyak sulfat hasil penelitian termasuk minyak sulfat komersial, semuanya memenuhi persyaratan IS: 6357-1971, spesifikasi minyak sulfat untuk kulit yang mempersyaratkan kadar minyak minimal $60 \%$. Hasil uji kadar minyak pada penggunaan $10 \%$ $\mathrm{H}_{2} \mathrm{SO}_{4}$ nilainya lebih tinggi dari pada penggunaan $12,5 \%$ $\mathrm{H}_{2} \mathrm{SO}_{4}$. Hal ini mengindikasikan bahwa semakin banyak jumlah $\mathrm{H}_{2} \mathrm{SO}_{4}$ yang ditambahkan pada proses sulfatasi, maka semakin banyak asam sulfat yang bereaksi dengan asam lemak dari minyak.

\section{pH}

Nilai $\mathrm{pH}$ dari minyak sulfat hasil penelitian dalam kisaran antara 6,6 -7,75 yang ditunjukkan pada Tabel 1 . Nilai $\mathrm{pH}$ minyak sulfat hasil penelitian termasuk minyak sulfat komersial, semuanya memenuhi persyaratan IS:6357-1971, spesifikasi minyak sulfat untuk kulit yang mempersyaratkan $\mathrm{pH}$ 6,5-8. Semakin banyak jumlah $\mathrm{H}_{2} \mathrm{SO}_{4}$ yang ditambahkan, maka semakin rendah $\mathrm{pH}$ yang dihasilkan, hal ini mengindikasikan bahwa semakin banyak asam sulfat yang ditambahkan, maka semakin banyak asam sulfat yang bereaksi dengan asam lemak dari minyak. Semakin lama waktu sulfatasi, maka $\mathrm{pH}$ minyak semakin rendah, hal ini mengindikasikan bahwa proses sulfatasi perlu waktu. Waktu yang optimal adalah selama 4 jam.

\section{Kadar $\mathrm{SO}_{3}$ Terikat}

Uji kadar $\mathrm{SO}_{3}$ terikat dimaksudkan untuk mengetahui jumlah asam sulfat yang mengadisi ikatan rangkap setelah terjadinya reaksi sulfatasi (Helmi, 2001). Kadar $\mathrm{SO}_{3}$ terikat minyak sulfat hasil penelitian berkisar antara 6,67,75, yang ditunjukkan pada Tabel 1 .

Semakin banyak kandungan $\mathrm{SO}_{3}$ yang terikat pada minyak sulfat, bila diaplikasikan pada kulit $\mathrm{SO}_{3}$ akan berikatan dengan $\mathrm{H}_{2} \mathrm{O}$ sehingga membentuk $\mathrm{H}_{2} \mathrm{SO}_{4}$ yang akan merusak kulit yang disamak. Kadar $\mathrm{SO}_{3}$ terikat yang baik pada minyak sulfat adalah 3-7\% (Suseno, 2002). Semakin besar jumlah asam sulfat yang digunakan memungkinkan molekul-molekul asam sulfat bereaksi dengan ikatan rangkap dari asam lemak penyusun minyak, sehingga ikatan rangkap teradisi oleh asam sulfat yang menyebabkan jumlah $\mathrm{SO}_{3}$ terikat menjadi semakin tinggi (Helmi, 2001). Hal ini dapat dilihat pada Tabel 1, bahwa 
kadar $\mathrm{SO}_{3}$ terikat pada penggunaan $12,5 \% \mathrm{H}_{2} \mathrm{SO}_{4}$ lebih tinggi dari pada penggunaan $10 \% \mathrm{H}_{2} \mathrm{SO}_{4}$.

\section{Angka Iodine}

Angka Iodine adalah jumlah Iod dalam garam yang ditambahkan untuk menetralkan 100 gram lemak, yang menentukan tingkat kejenuhan dari asam lemak bebas dalam minyak. Angka Iodine minyak kelapa sawit curah sebesar 49,95. Minyak kelapa sawit tersebut setelah dilakukan proses sulfatasi menggunakan $10 \%$ dan $12,5 \%$ $\mathrm{H}_{2} \mathrm{SO}_{4}$ dengan waktu sulfatasi $0,1,2,3$, dan 4 jam, terjadi penurunan angka Iodine. Penurunan angka Iodine paling banyak pada sulfatasi menggunakan $10 \% \mathrm{H}_{2} \mathrm{SO}_{4}$ dibandingkan menggunakan $12,5 \% \mathrm{H}_{2} \mathrm{SO}_{4}$. Hal ini dapat dilihat pada Tabel 1. Penurunan angka Iodine minyak tersulfatasi menunjukkan bahwa beberapa ikatan rangkap telah teradisi oleh asam sulfat dan tidak dapat di-adisi oleh molekul $\mathrm{I}_{2}$. Semakin kecil jumlah angka Iodine, maka semakin banyak jumlah ikatan rangkap yang teradisi oleh asam sulfat, karena ikatan rangkap yang telah teradisi oleh asam sulfat tidak dapat diadisi lagi oleh molekul $\mathrm{I}_{2}$. (Helmi, 2001). Reaksi utama pada sulfating agent dengan ikatan rangkap yang ditunjukkan dengan turunnya angka Iodine (Kassahun, 2014).

\section{Aplikasi Minyak Sulfat pada Kulit}

\section{Hasil pengamatan kulit tersamak secara visual}

Menurut Nurbalia (2000), penggunaan minyak sulfat lebih dari 5\% akan menyebabkan bercak-bercak lemak (fatty spew). Hal serupa disampaikan oleh Zengin dan Afsar (2009) bahwa penggunaan emulsi minyak lebih dari $5 \%$ akan menyebabkan fatty spew. Pengamatan kulit tersamak secara visual dilakukan untuk mengetahui ada tidaknya fatty spew pada permukaan kulit tersamak. Hasil pengamatan terhadap 10 kulit tersamak hasil aplikasi $8 \%$ minyak sulfat pada kulit dapat dilihat pada Gambar 2.

Efek peminyakan pada kulit tidak berpengaruh pada jumlah $\mathrm{H}_{2} \mathrm{SO}_{4}$ yang ditambahkan, maupun waktu sulfatasi minyak. Semua kulit tersamak yang dihasilkan, secara visual tidak terlihat adanya fatty spew. Hal ini disebabkan karena dalam proses penyamakan ulang ditambahkan bahan penyamak nabati. Menurut Sarkar (1995), bahwa minyak sulfat lebih cocok digunakan untuk kulit yang disamak dengan bahan penyamak nabati. Adanya bahan penyamak nabati mengindikasikan bahwa penyerapan minyak sulfat ke dalam jaringan kulit lebih mudah terpenetrasi, sehingga tidak terbentuk fatty spew. Menurut Tancous (1974), kulit samak nabati tidak rentan terhadap pembentukan fatty spew.

\section{Hasil uji sifat fisik dan kimia kulit tersamak}

Hasil uji sifat fisik kulit meliputi uji ketebalan, kekuatan sobek, kekuatan tarik, kemuluran, dan kadar minyak (uji kimia) dapat dilihat pada Tabel 2 berikut ini.

\section{Ketebalan}

Ketebalan kulit adalah salah satu parameter yang digunakan dalam menentukan kualitas kulit. Ketebalan awal kulit dapat disesuaikan selama produksi kulit, yaitu dengan cara di-shaving pada saat kulit masih dalam kondisi wet blue. Ketebalan kulit hasil penelitian berkisar antara 0,76-0,90 mm, yang ditunjukkan pada Tabel 2 . Nilai ketebalan untuk semua kulit hasil penelitian telah memenuhi persyaratan SNI 0253:2009 (BSN, 2009), Kulit bagian atas alas kaki-kulit kambing, mempersyaratkan ketebalan minimum $0,6 \mathrm{~mm}$.

\section{Kekuatan Sobek}

Nilai kekuatan sobek kulit hasil penelitian berkisar antara 8,44 - 20,79 N/cm, yang ditunjukkan pada Tabel 1. SNI 0253: 2009 (BSN, 2009), Kulit bagian atas alas kaki-kulit kambing, mempersyaratkan kekuatan sobek minimal $15 \mathrm{~N} / \mathrm{cm}$. Nilai kekuatan sobek terbesar dicapai pada penggunaan $8 \%$ minyak sulfat $(12,5$ - 3) dengan nilai $20,79 \mathrm{~N} / \mathrm{cm}$. Daya tahan sobek dan tarikan kulit diperbesar oleh adanya peminyakan, karena minyak bersifat sebagai pelumas pada serat kulit yang bergesekan. Lapisan lemak pada permukaan serat akan memudahkan serat bergesekan satu sama lain sehingga kulit lebih fleksibel atau mudah dilekukkan. Menurut Helmi (2000), penetrasi minyak ke dalam kulit menyebabkan serat kulit terisi dan semakin banyak minyak yang ikut berikatan dengan ikatan silang kolagen kulit, sehingga kekuatan sobek akan bertambah.

\section{Kekuatan Tarik}

Sifat fisis kulit seperti kekuatan tarik, tergantung pada proses peminyakan (Tawfik et al., 2017). Nilai kekuatan tarik kulit hasil penelitian berkisar antara 7,49-20,52 N/ $\mathrm{mm}^{2}$, yang ditunjukkan pada Tabel 2. SNI 0253: 2009, Kulit bagian atas alas kaki-kulit kambing (BSN, 2009), yang mempersyaratkan kekuatan tarik minimal $16 \mathrm{~N} /$ $\mathrm{mm}^{2}$. Nilai kekuatan tarik terbesar dicapai penggunaan $8 \%$ minyak sulfat $(12,5-2)$ dengan nilai $20,52 \mathrm{~N} / \mathrm{mm}^{2}$. Kekuatan tarik merupakan karakteristik fleksibilitas jaringan kulit, disamping untuk kekuatan dari jaringan kolagen (Quadery et al., 2015) dan karakteristik sifat fisis dari kulit tergantung pada proses peminyakan (Nyamunda et al., 2013).

\section{Kemuluran}

Kemuluran mempengaruhi kelemasan dan fleksibilitas, kekuatan dari matriks kulit (Quadery et al., 2015). Nilai kemuluran kulit hasil penelitian berkisar antara 45,04-65,71\%. SNI 0253: 2009 (BSN, 2009), Kulit bagian atas alas kaki-kulit kambing, mempersyaratkan kemuluran maksimum 55\%.

\section{Kadar Minyak}

Kadar minyak kulit hasil penelitian berkisar antara 4,45 - 10,55 \%, yang ditunjukkan pada Tabel 2. SNI 0253: 2009, Kulit bagian atas alas kaki-kulit kambing (BSN, 2009), mempersyaratkan kadar minyak 4 - 8\%. Dari hasil analisis sifat fisis dan kadar minyak dalam penelitian ini, perlakuan yang optimal adalah kulit dengan aplikasi $8 \%$ minyak sulfat dengan perlakuan $(12,5-4)$. 


\section{Analisis mikroskopik SEM - EDX}

Hasil analisis SEM-EDX meliputi uji komponenkomponen logam dan hasil pengamatan struktur kulit secara mikrokopik. Analisis SEM-EDX dilakukan terhadap sampel kulit tersamak yaitu hasil aplikasi minyak sulfat pada kulit. Hasil analisis komponen logam yang terdeteksi pada sampel kulit meliputi karbon, natrium oksida, silika oksida, sulfit, kalium oksida, krom (III)

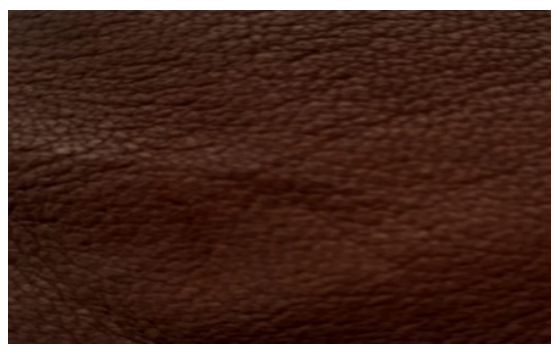

$(10-0)$

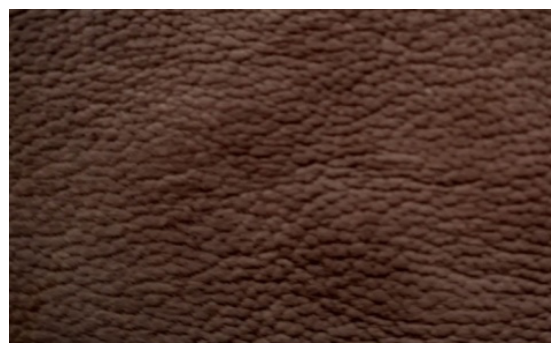

$(10-2)$

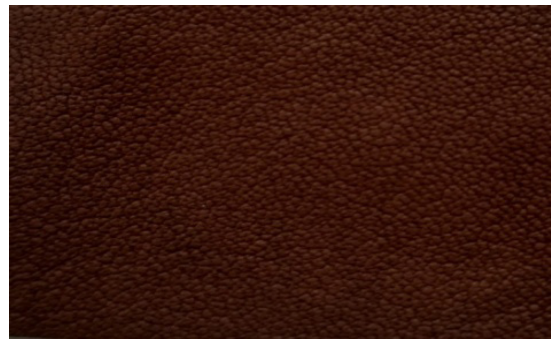

$(10-4)$

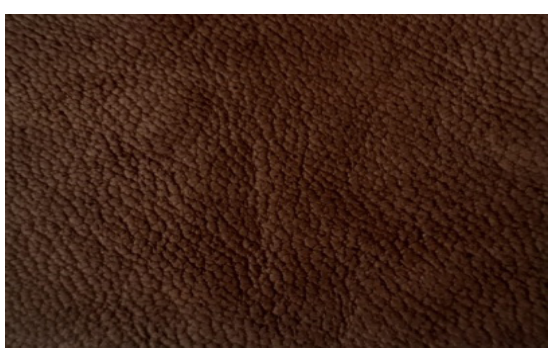

$(12,5-1)$

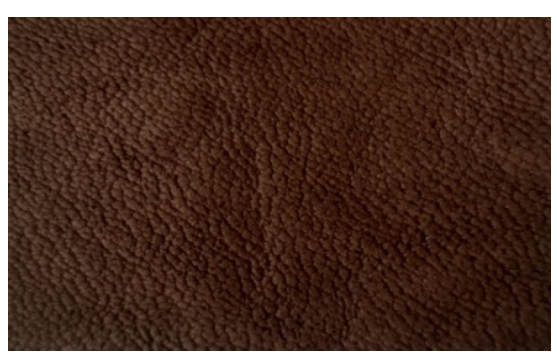

$(12,5-3)$ oksida; klorida; besi oksida; alumina. Unsur logam yang terkait dengan proses peminyakan adalah Sulfit $\left(\mathrm{SO}_{3}\right)$. Adanya sulfit pada kulit menunjukkan bahwa minyak sulfat yang mengandung sulfit $\left(\mathrm{SO}_{3}\right)$ yang diaplikasikan pada kulit bereaksi atau terpenetrasi kedalam matrik jaringan kulit. Kandungan sulfit (\% berat) minyak sulfat dibandingkan dengan kandungan sulfit pada kulit tersamak dapat dilihat pada Tabel 3.

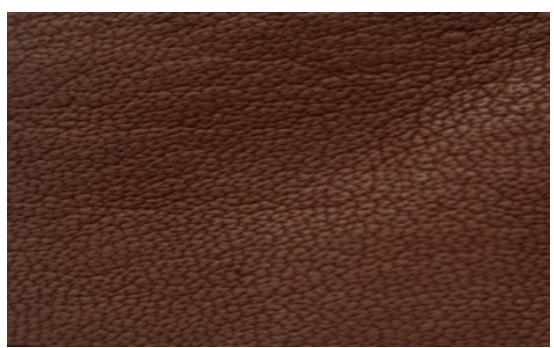

$(10-1)$

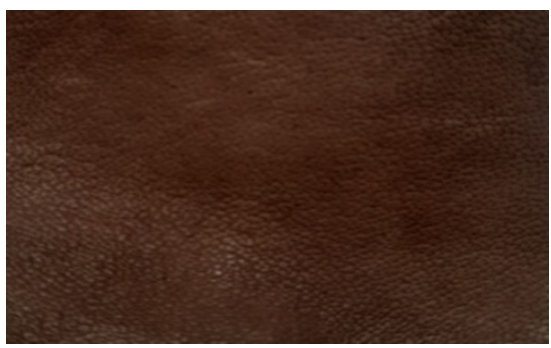

$(10-3)$

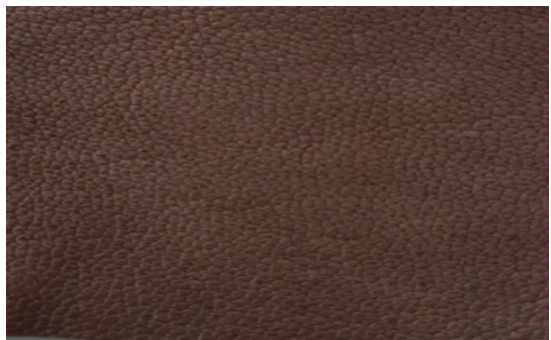

$(12,5-0)$

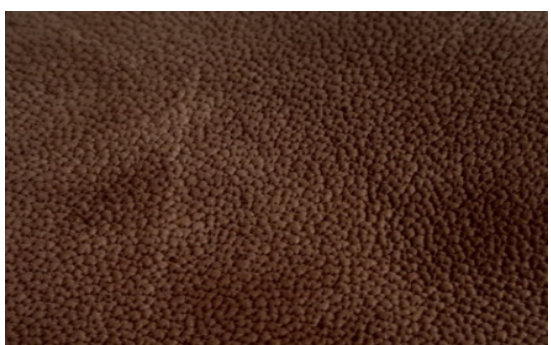

$(12,5-2)$

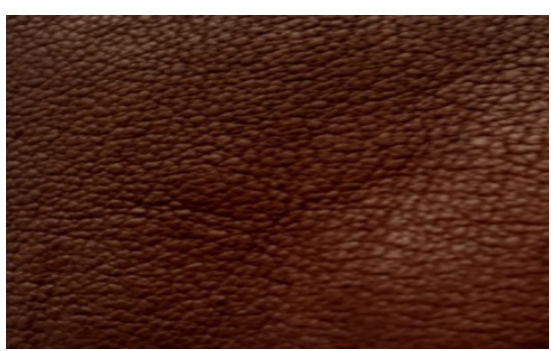

$(12,5-4)$

Gambar 2. Permukaan kulit tersamak. 
Tabel 2. Hasil uji ketebalan, kekuatan sobek, kekuatan tarik, kemuluran, dan kadar minyak.

\begin{tabular}{cccccc}
\hline Kode & $\begin{array}{c}\text { Ketebalan } \\
(\mathrm{mm})\end{array}$ & $\begin{array}{c}\text { Kekuatan sobek } \\
(\mathrm{N} / \mathrm{cm})\end{array}$ & $\begin{array}{c}\text { Kekuatan tarik } \\
\left(\mathrm{N} / \mathrm{mm}^{2}\right)\end{array}$ & $\begin{array}{c}\text { Kemuluran } \\
(\%)\end{array}$ & $\begin{array}{c}\text { Kadar minyak } \\
(\%)\end{array}$ \\
\hline$(10-0)-8$ & 0,82 & 19,51 & 19,74 & 65,71 & 6,75 \\
$(10-1)-8$ & 0,80 & 16,19 & 20,35 & 49,12 & 9,47 \\
$(10-2)-8$ & 0,88 & 17,48 & 17,89 & 80,16 & 8,18 \\
$(10-3)-8$ & 0,88 & 8,44 & 7,49 & 51,13 & 7,31 \\
$(10-4)-8$ & 0,84 & 20,44 & 13,01 & 61,99 & 9,63 \\
$(12,5-0)-8$ & 0,84 & 17,15 & 7,36 & 57,43 & 10,55 \\
$(12,5-1)-8$ & 0,86 & 13,07 & 11,97 & 56,76 & 5,25 \\
$(12,5-2)-8$ & 0,76 & 13,89 & 20,52 & 45,04 & 4,45 \\
$(12,5-3)-8$ & 0,84 & 20,79 & 18,01 & 61,69 & 8,52 \\
$(12,5-4)-8$ & 0,90 & 15,60 & 16,77 & 48,36 & 7,57 \\
K-8 & 0,78 & 11,49 & 14,79 & 48,81 & 3,95 \\
\hline
\end{tabular}

Tabel 3. Kandungan sulfit (\% berat) minyak sulfat dan kulit tersamak.

\begin{tabular}{cccc}
\hline No. & Kode sampel & \multicolumn{2}{c}{${\text { Kandungan } \mathrm{SO}_{3}(\%)}$} \\
\cline { 3 - 4 } & & Minyak sulfat & Kulit tersamak \\
\hline 1. & $(10-0)$ & 5,49 & 9,69 \\
2. & $(10-1)$ & 4,44 & 8,23 \\
3. & $(10-2)$ & 4,56 & 6,58 \\
4. & $(10-3)$ & 4,63 & 5,26 \\
5. & $(10-4)$ & 5,69 & 5,64 \\
6. & $(12,5-0)$ & 7,71 & 4,11 \\
7. & $(12,5-1)$ & 7,81 & 5,00 \\
8. & $(12,5-2)$ & 6,63 & 5,11 \\
9. & $(12,5-3)$ & 7,45 & 5,79 \\
10. & $(12,5-4)$ & 6,49 & 4,45 \\
11. & Kontrol III & 5,09 & 6,25 \\
\hline
\end{tabular}

Dari Tabel 3 dapat dilihat bahwa terjadi kenaikan dan penurunan komponen sulfit setelah minyak sulfat diaplikasikan pada kulit. Kenaikan komponen sulfit terjadi pada aplikasi minyak sulfat dengan $10 \%$ asam sulfat pada sulfatasi minyak. Penurunan komponen sulfit terjadi pada aplikasi minyak sulfat dengan $12,5 \%$ asam sulfat pada sulfatasi minyak. Hal tersebut menunjukkan bahwa penggunaan minyak sulfat dengan $12,5 \%$ asam sulfat pada sulfatasi minyak dengan variasi waktu sulfatasi $0,1,2,3$, dan 4 jam, lebih baik dibandingkan dengan penggunaan $10 \%$ asam sulfat pada sulfatasi minyak. Semakin banyak kandungan $\mathrm{SO}_{3}$ yang terikat pada minyak sulfat, bila diaplikasikan pada kulit $\mathrm{SO}_{3}$ akan berikatan dengan $\mathrm{H}_{2} \mathrm{O}$ sehingga membentuk $\mathrm{H}_{2} \mathrm{SO}_{4}$ yang akan merusak kulit yang disamak (Suseno, 2002). Kadar sulfit terbaik yaitu dengan kandungan sulfit yang rendah pada kulit. Pada penelitian ini kadar sulfit terbaik adalah sampel kulit dengan kode $(12,5-0)$ dengan nilai $4,11 \%$ disusul kode $(12,5-4)$ dengan nilai $4,45 \%$.

\section{Hasil Analisis Struktur Kulit secara Scanning Electron Microscopic (SEM)}

Analisis SEM dimaksudkan untuk melihat kedalaman struktur jaringan kulit dan melihat pengaruh minyak pada permukaan kulit (grain surface). Hasil SEM kulit dengan perbesaran $100 \mathrm{X}$ dapat dilihat pada Gambar 3.
Proses peminyakan pada kulit (fatliquoring) adalah perlakuan memasukkan "emulsi minyak dalam air" ke dalam serat kulit. Fungsi minyak adalah mencegah struktur serat berhenti (resticking) selama pengeringan, karena kulit yang mengalami pengeringan, air diantara serat kulit berkurang banyak, sehingga struktur jaringan tertutup dan terjadi interaksi yang kuat. Minyak harus terikat dengan baik ke dalam jaringan kulit, jika tidak terikat dengan baik maka dapat bermigrasi ke dalam permukaan kulit dan dapat melemahkan ikatan yang terbentuk serta kulit sulit untuk diberi cat tutup (di-finish) karena lapisan film yang terbentuk tidak dapat melekat pada permukaan kulit (Unido, 1976). Disamping itu bila minyak sulfat yang digunakan tidak kompatibel dengan serat-serat kulit maka akan terjadi fatty spew (Tuck, 1993). Fatty spew dapat terjadi karena masih banyaknya asam lemak jenuh yang terkandung di dalam minyak sulfat yaitu adanya Methyl Palmitate dan Stearat. Dari Gambar 3 nampak bahwa tidak terdapat bercak-bercak lemak. Menurut Sarkar (1995), bahwa minyak sulfat lebih cocok digunakan untuk kulit yang disamak dengan bahan penyamak nabati. Pada penelitian proses penyamakan ulang ditambahkan bahan penyamak nabati, sehingga dengan adanya bahan penyamak nabati mengindikasikan bahwa penyerapan minyak sulfat kedalam jaringan kulit lebih mudah terpenetrasi dan tidak terbentuk bercak-bercak lemak. 
Menurut Tancous (1974), kulit samak nabati tidak rentan terhadap pembentukan bercak-bercak lemak.

Ditinjau dari struktur kulit, Gambar 3 menunjukkan bahwa semakin lama waktu sulfatasi maka struktur kulit tampak lebih padat/kompak baik pada penggunaan asam

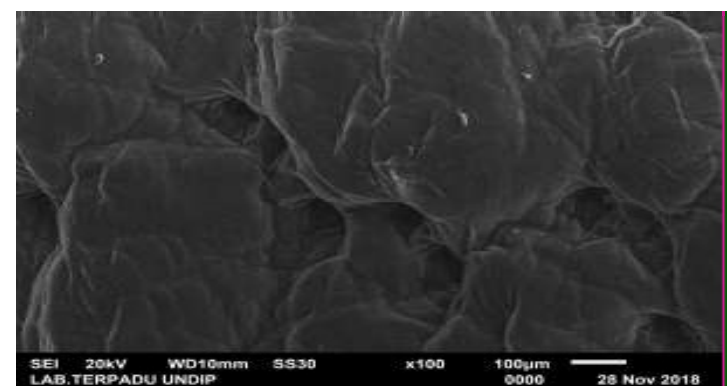

$(10-0)$

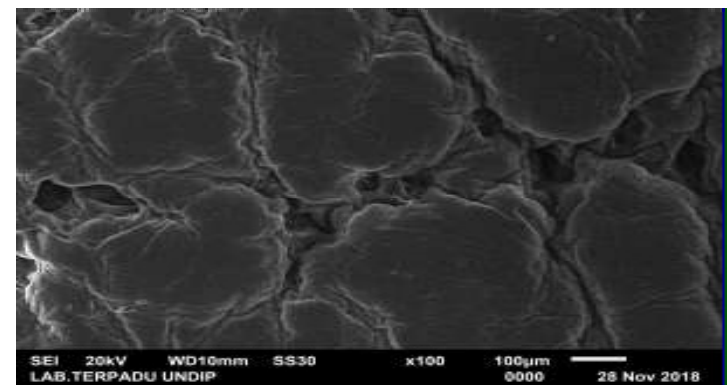

$(10-1)$

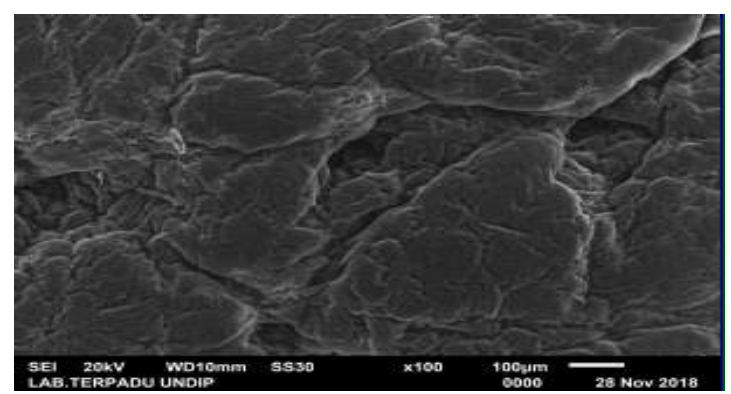

$(10-2)$

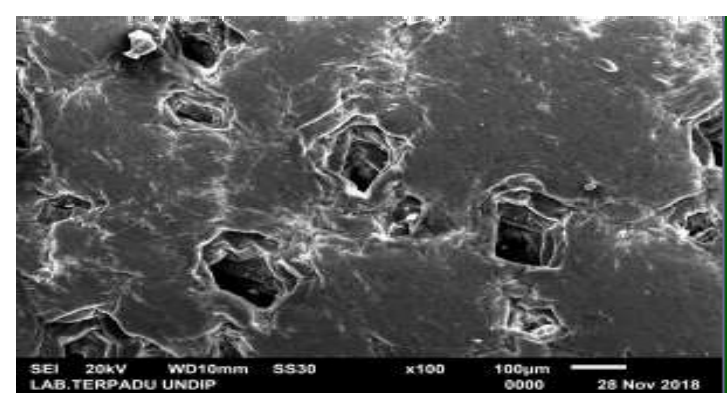

$(10-3)$

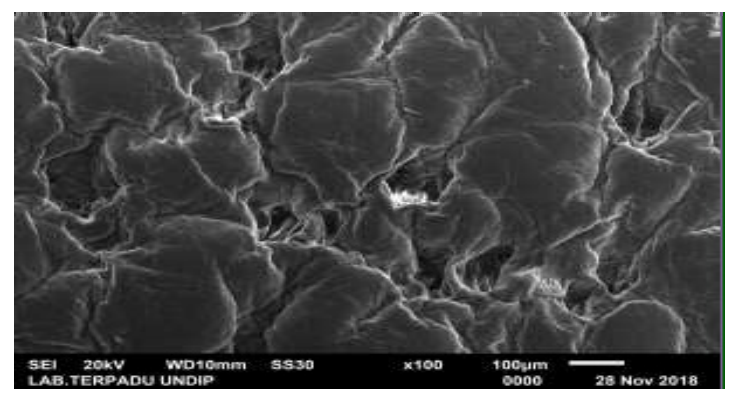

$(10-4)$ sulfat $10 \%$ maupun $12,5 \%$. Dari hasil pengamatan SEM, penggunaan asam sulfat pada $12,5 \%$ proses sulfatasi tampak lebih padat/kompak dibandingkan dengan penggunaan asam sulfat $10 \%$. Hasil paling baik adalah aplikasi minyak sulfat dengan kode $(12,5-4)$ yaitu

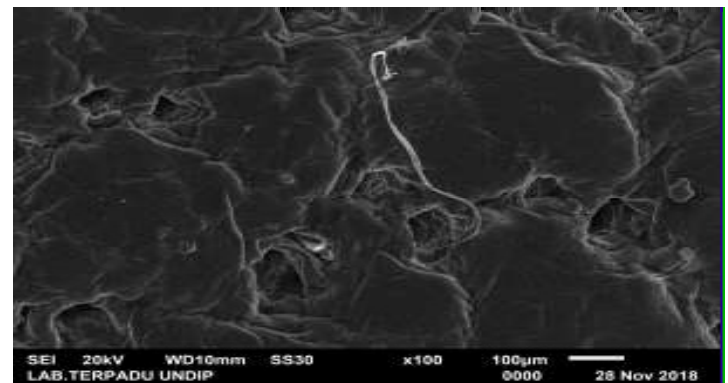

$(12,5-0)$

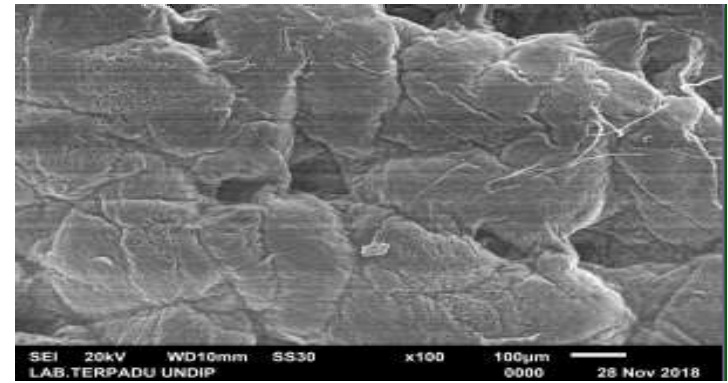

$(12,5-1)$

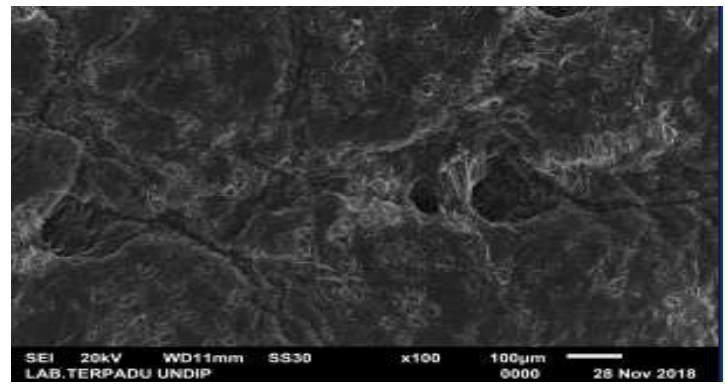

$(12,5-2)$

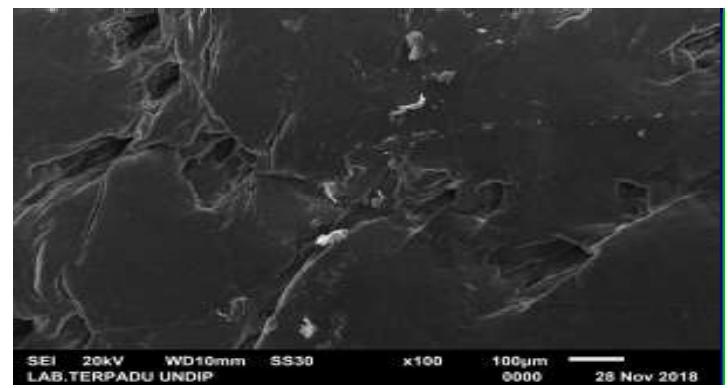

$(12,5-3)$

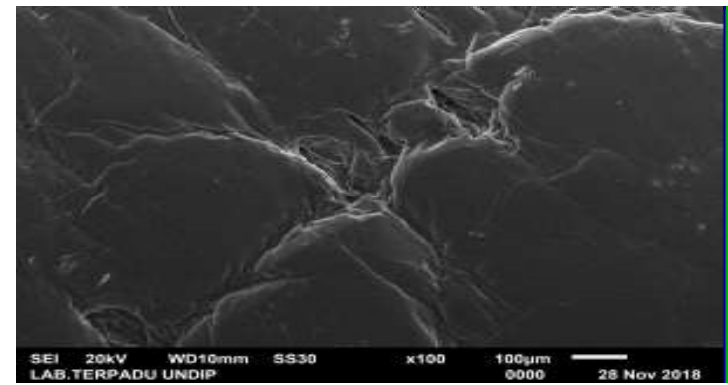

$(12,5-4)$

Gambar 3. SEM kulit kras dengan perbesaran 100x. 
minyak sulfat yang dibuat dari minyak kelapa sawit dengan penambahan $12,5 \%$ asam sulfat, waktu sulfatasi 4 jam.

\section{KESIMPULAN}

Minyak sulfat yang optimal adalah minyak sulfat dengan jumlah $\mathrm{H}_{2} \mathrm{SO}_{4}$ sebesar $12,5 \%$ dan waktu sulfatasi 4 jam. Secara kimia minyak sulfat $(12,5-4)$ memenuhi persyaratan IS: IS: 6357-1971, spesifikasi minyak sulfat untuk kulit dengan nilai kadar air 5,16\%; kadar abu 2,17\%; Total alkalinitas $0,79 \%$; kadar lemak 88,42\%; pH 6,60; kadar SO3 terikat $6,49 \%$.

Jumlah $\mathrm{H}_{2} \mathrm{SO}_{4}(10 \%$ dan $12,5 \%)$ dan waktu sulfatasi $(0,1,2,3$, dan 4 jam) berpengaruh terhadap kualitas kulit tersamak. Aplikasi 8\% minyak sulfat (12,5-4) pada kulit merupakan perlakuan yang optimal dan memenuhi persyaratan SNI 0253:2009 (BSN, 2009), Kulit bagian atas alas kaki-kulit kambing. Kualitas kulit tersamak yang dihasilkan yaitu dengan nilai kekuatan sobek 15,60 N/ $\mathrm{cm}$; kekuatan tarik 16,77 N/mm²; kemuluran 48,36\%; dan kadar minyak 7,57\%, serta secara visual kulit hasil aplikasi minyak sulfat (12,5 - 4) tidak nampak adanya fatty spew.

\section{UCAPAN TERIMA KASIH}

Penulis mengucapkan terima kasih kepada Kepala Balai Besar Kulit, Karet dan Plastik serta Kepala Bidang Sarana Riset dan Standardisasi atas ijin menggunakan fasilitas penelitian dan kepada semua pihak yang telah membantu penelitian hingga terwujudnya tulisan ini.

\section{DAFTAR PUSTAKA}

BSN (Badan Standardisasi Nasional). (2009). SNI 0253:2009 Kulit bagian atas alas kaki - kulit kambing. Jakarta, Indonesia: BSN.

Covington, A. D. (2009). Tanning chemistry: The science of leather. Cambridge, UK: RSC Publishing.

Hariyadi P., (2010), Sepuluh Karakter Unggul Minyak Sawit, Infosawit Oktober 2010

Helmi. (2001). Mempelajari proses sulfatasi minyak jarak sebagai fatliquor (Skripsi). Institut Pertanian Bogor, Bogor.

Indian Standards Institution. (1971). IS:6357-1971 Specification for sulphated oil for leather fatliquoring. New Delhi, India: Indian Standards Institution.

Kasmudjiastuti, E., Griyanitasari, G., Rahmawati, D., \& Sugihartono. (2018). Sintesis dan karakterisasi minyak kelapa sawit untuk agensia peminyakan pada penyamakan kulit. Majalah Kulit, Karet, dan Plastik, 34(1), 19-25. https://doi.org/10.20543/mkkp.v34i1.3893

Kassahun, W. (2014). Preparation of leather fatliquor cum filler from fleshing waste for retanning process in leather manufacture (Thesis). Ethiopia University, Adis Ababa.

Megahed, M. G., \& Nashy, E. S. H. A. (2010). Ester phosphate of discarded palm oil from potato chip factories as fatliquoring agent. Journal of American Science, 6(12), 617-626.

Nurbalia, E. (2000). Penerapan minyak sulfat dari bahan dasar minyak sawit pada kulit wetblue sapi untuk garmen ditinjau dari kekuatan tarik dan elongasinya (Laporan Penelitian). Akademi Teknologi Kulit, Yogyakarta.

Nyamunda, B. C., Moyo, M., \& Chigondo, F. (2013). Synthesis of fatliquor from waste bovine fat for use in small scale leather industry. Indian Journal of Chemical Technology, 20, 116-120.

Quadery, A. H., Uddin, M. T., Azad, M. A. K., Chowdhury, M. J., Deb, A. K., \& Hassan, M. N. (2015). Fatliquor preparation from Karanja seed oil (Pongamia pinnata L.) and its application for leather processing. IQSR Journal of Applied Chemistry, 8(1), 54-58.

Rofiqi, D. M. (2016). Strategi percepatan pengembangan industri turunan minyak sawit mentah (MSM) di Indonesia (Thesis). Institut Pertanian Bogor, Bogor.

Santos, L. M., \& Gutterres, M. (2007). Reusing of a hide waste for leather fatliquoring. Journal of Cleaner Production, 15(1), 12-16. https://doi.org/10.1016/j.jclepro.2006.01.025

Sarkar, K. T. (1995). Theory practice leather manufacture. Madras, India: The CLS Press.

Strijbos, L., Saumweber, R., Hess, M., Gabagnou, C., \& Fennen, J. (2012). High-fastness fatliquors from sustainable resources. World Leather, Apr/May.

Suseno, H.(2002). Proses pembuatan minyaksulfatmenggunakan bahan dasar minyak kelapa sawit dalam proses sulfatasi. Yogyakarta, Indonesia: Penerbit ATK.

Tancous, J. J. (1974). A study of fat spew by gas chromatography. Journal of the American Leather Chemists' Association, 69, 66-84.

Tawfik, H. M., Gasmelseed, G. A., \& Mohammed, F. E. F. (2017). Using characterization and synthesis of fatliquor from Sudanese castor oil. Indian Journal of Medical Research and Pharmaceutical Sciences, 6(2), 11-16. http:// doi.org/10.5281/zenodo.266664

Tournier, R. A. (2017). Diagnosis, presentation, and treatment of fatty spew in the tannery. Journal of the American Leather Chemists'Association, 110(8), 260-276.

Tuck, D. H. (1993). The manufacture of upper leathers. London, UK: Tropical Products Institute.

Unido. (1976). Acceptable Quality Levels in Leather. New York, USA: United Nations.

Wang, C., Li, T., \& Feng, S. (2012). Synthesis of fatliquor from palm oil and hydroxyl-terminated organosilicon. Asian Journal of Chemistry, 24(1), 63-76.

Zengin, G., \& Afsar, A. (2009). An Investigation on the leather used natural fat emulsion in the fatliquoring process. in XXX IULTCS Congress. Bejing, China: International Union of Leather Technologists and Chemists Societies. 
